\title{
Low-Resolution Vehicle Image Recognition Technology by Frame-Composition of Moving Images
}

\author{
Yusuke Kanzawa Non-member (Kobe University, yu-suke@cs25.scitec.kobe-u.ac.jp) \\ Hiroki Kobayashi Non-member (Kobe University) \\ Takenao Ohkawa Member (Kobe University) \\ Toshio Ito Non-member (DAIHATSU MOTOR CO.,LTD.)
}

Keywords: super-resolution, vehicle recognition, frame-composition, computer vision

Developing on-board automotive driver assistance systems aiming to alert drivers about driving environments and possible collision with other vehicles has attracted a lot of attention recently. Especially, the forward vehicle recognition methods by a camera on vehicle have been intensively studied. In the forward vehicle recognition, however, it is difficult to detect the features of vehicle from a distant vehicle image by conventional methods because the image is too lowresolution(LR).

This paper presents a vehicle image recognition method for detecting features of a distant vehicle by frame-composition of time barring images. To detect vehicle features of a distant LR vehicle image, we use the time barring images obtained from a camera on vehicle, and utilize super-resolution (SR) image reconstruction. SR image reconstruction uses the shift of the topology occurred sampling on different points, and reconstructs higher frequency components of the original signal by canceling out the alias components.

The proposed method is composed of the following four stages.

(1) Detecting the composing position

We detect the shift in each sampling positions to the frame images obtained from the camera on the vehicle.

(2) Frame-Composition

By composing the frame images detected in the previous stage, the alias components of frame images are canceled out and higher frequency components of the frame images are reconstructed.

(3) Image restoration

By using image restoration method to composed image, the blur or slightly out of focus occurred from composition is improved.

(4) Detecting vehicle's feature

By detecting the vehicle's feature on the improved composed image, the effectiveness of our method will be confirmed.

The frame image obtained without proposed method is

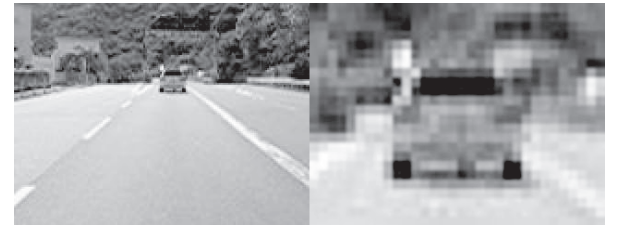

Fig. 1. Input Image on Real Road

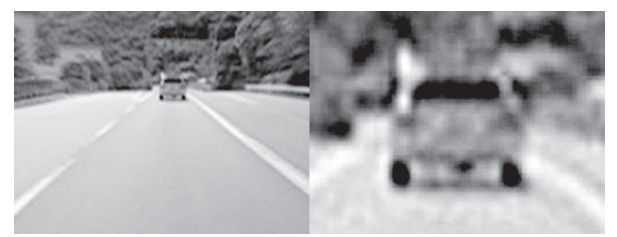

Fig. 2. SR Image on Real Road

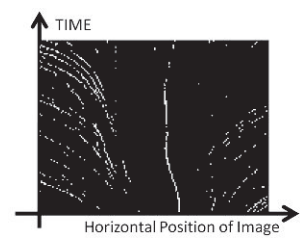

Fig. 3. Edge Transition (Input Image)

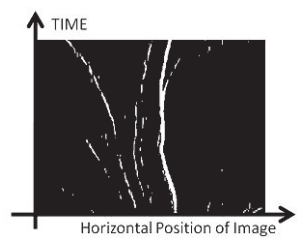

Fig. 4. Edge Transition (SR Image) shown in Fig. 1, and the composed image of Fig. 1 by the proposed method is shown in Fig. 2. The transition graphs created from Fig. 1 and Fig. 2 are shown in Fig. 3 and Fig. 4, respectively.

Compared Fig. 3 and Fig. 4, the vehicle's left outline in Fig. 3 cannot be obtained because an edge of vehicle's left outline is weak. On the other hand, after the proposed technique is applied, vehicle's right outline can be correctly obtained. These results show the improvement of accuracy of detecting the vehicle's outlines by using the proposed method. 


\title{
動画像のフレーム合成による 低解像度車両認識技術に関する研究
}

\author{
非会員 寒澤 佑介* ${ }^{*}$ 非会員 小林 宏樹 \\ 正 員 大川 剛直* 非会員 伊東 敏夫**
}

\author{
Low-Resolution Vehicle Image Recognition Technology \\ by Frame-Composition of Moving Images
}

\begin{abstract}
Yusuke Kanzawa*, Non-member, Hiroki Kobayashi, Non-member, Takenao Ohkawa*, Member,
Toshio Ito**, Non-member
\end{abstract}

\begin{abstract}
Developing on-board automotive driver assistance systems aiming to alert drivers about driving environments, and possible collision with other vehicles has attracted a lot of attention lately. Especially, many researchers have suggested the forward vehicle recognition technology by a camera on vehicle. In the forward vehicle recognition, however, it is difficult to detect the features of vehicle from a distant vehicle image by conventional methods because the image is too low-resolution (LR). This paper presents vehicle image recognition technology for detecting of the features of a distant vehicle by frame-composition of moving images. To detect the vehicle features of a distant LR vehicle image, we use the moving images obtained from the camera on the vehicle, and utilize super-resolution (SR) image reconstruction. SR image reconstruction is to use signal processing techniques to obtain a high-resolution (or sequence) image from observed multiple LR images. Use of this technique on real road image, we show the effectiveness of the proposed techniques.
\end{abstract}

キーワード：超解像処理, 車両認識, フレーム合成, コンピュータビジョン

Keywords: super-resolution, vehicle recognition, frame-composition, computer vision

\section{1. はじめに}

近年, 自動車と道路が一体のシステムとして機能するこ とで自動車交通をより安全, 円滑で環境に調和したものに しょうとするITS(Intelligent Transport Systems) の研究 が進められている。また, ASV(Advanced Safety Vehicle) 技術の応用として高速道路での追従走行機能を搭載した車 両が製品化され，より広範囲な交通状況での追従走行や衝 突被害の軽減, 自動操舵制御を行うための研究も進められ ている。

そのようなITS の実現に向けた研究の一つに車両に搭載 した車載カメラによる先行車両の認識が挙げられ, 車載カメ ラによって撮影された車両前方の道路情景画像の各フレー

\footnotetext{
* 神戸大学大学院, 工学研究科

于 657-8501 兵庫県神戸市灘区六甲台町 1-1

Kobe University, Graduate School of Engineering

1-1, Rokkoudaicho, Nadaku, Kobe-shi, Hyogo 657-8501

** ダイハツ工業 (株), 電子技術部

干 563-8651 大阪府池田市ダイハッ町 1 番 1 号

DAIHATSU MOTOR CO.,LTD., Electronics Engineering Div.

1-1, Daihatsucho, Ikeda-shi, Osaka 563-8651
}

ムより先行車両を抽出・認識する手法が数多く提案されてい る(1) (2)。これらの手法の大部分は, 車両輪郭や車両のテー ルランプなどの車両特徴を用いて先行車両を認識している。 しかしながら, 先行車両が遠方にある場合には, 解像度不 足のために車両特徵の抽出が難しく, 車両特徴を使用する 先行車両認識手法では, 先行車両を正しく認識することが 困難であるという課題がある。特に遠方では，車両輪郭を 抽出する際に, 周囲の道路構造物の輪郭情報が強く抽出さ れ，車両輪郭の情報が抽出できないという現状がある。

以上の背景に基づき, 本論文では, 従来の先行車両認識手 法の大きな問題点である, 遠方にある先行車両の認識を目 的とする。その改善策の一つとして, 従来手法に扔いて車両 特徴が正しく抽出できる状態にまで, 先行車両の解像度を 向上させる手法が考えられる。それに向けて, 本論文では車 載カメラから獲得される動画像に着目し, 動画像から獲得 される複数枚のフレーム画像を合成することで解像度の向 上とノイズの低減を図る手法を提案する。観測された複数 の低解像度画像 (low-resolution image) から 1 枚の高解像 度画像 (super-resolution image) を獲得するという手法は, 画像処理の分野では総じて超解像処理 (super-resolution 
image reconstruction) (3) (4) (5) と呼ばれ，本研究でもその 考え方を導入し解像度の向上を図る。

\section{2. 動画像のフレーム合成による低解像度車両の認識}

提案手法は超解像処理の考え方に基づき，次に示す 4 段 階の手順により構成される。

（1）複数枚のフレーム画像における合成位置特定処理 車載カメラから獲得された複数枚のフレーム画像データ自 身から, それぞれのフレーム画像データの撮影時の標本化 位置のずれを特定する。

（2）フレーム画像の重ね合わせ処理 標本化位置のずれが特定されたフレーム画像に対して重ね 合わせ処理をすることにより，折り返し歪みを打ち消し，原 信号の高周波成分を復元する。

（3）重ね合わせ画像の画像復元処理

重ね合わせを施された画像に対して画像復元処理をするこ とにより，合成処理によって生じたぶれやぼけを補正する。

（4）重ね合わせ画像に対する車両輪郭抽出処理 補正された重ね合わせ画像に対して, 車両輪郭抽出処理を することにより，先行車両認識精度の確認を行う。

以下，それぞれの手順について述べる。

$\langle\mathbf{2} \cdot \mathbf{1}\rangle$ フレーム画像の合成位置特定 フレーム画像 の重ね合わせ処理のために標本化位置のずれ量をフレーム 画像の画素間隔よりも小さい精度で知る必要がある。そこ で，サブピクセル補間を用いてマッチング処理を施すこと で，与えられた複数枚のフレーム画像データから標本化位 置のずれを特定する。

サブピクセル補間には，他の手法に比べ先鋭化された画 像が獲得できるという利点から, 双三次補間 (bicubic) 法 を用いる。このとき, 基準となる画素位置を $t=0$ とする 任意の $t$ に対して, 補間の重み関数 $w(t)$ は $(1)$ 式で表さ れる。

$$
w(t)= \begin{cases}\frac{2-5|t|^{2}+3|t|^{3}}{2}, & 0 \leq|t|<1 \\ \frac{4-8|t|+5|t|^{2}-|t|^{3}}{2}, & 1 \leq|t|<2 \quad \cdots(1) \\ 0, & 2 \leq|t|\end{cases}
$$

次に，サブピクセル補間を施されたフレーム画像に対し て，テンプレートマッチング処理を行う。テンプレートマッ チングでは，画像全体の移動量計測に対して強く, さらに サブピクセル精度での位置決定が可能という利点から, 最 小 2 乗マッチング (least squares matching) 手法を用いる。 最小 2 乗マッチングは, 類似度としてユークリッド距離の 2 乗（残差 2 乗和）を用いるテンプレートマッチングであ り, テンプレート画像 $\operatorname{Temp}(x, y)$ での残差の 2 乗和 $R((2)$ 式) が最小となるような, 位置 $(u, v)$ を決定する。ここで $\operatorname{Image}(x, y)$ は入力画像である。

$$
R=\sum_{x=0, y=0}\{\operatorname{Temp}(x, y)-\operatorname{Image}(u+x, v+y)\}^{2}
$$

本研究では，上記テンプレートマッチング処理を画像全 体に施し，それによって各々のフレーム画像間における標 本位置のずれの特定を行う。また, テンプレートマッチング 処理には通常長い処理時間が必要であり, 本論文のような 組み込みソフトウェアでは扱いが難しい処理であるが, 動 画像中における各フレーム画像間のずれはごく微小である という経験から，マッチング探索範囲を限定して処理時間 の向上を行っている。

$\langle 2 \cdot 2\rangle$ フレーム画像の重ね合わせ 上述の方法で標本 位置のずれを特定された各入力フレーム画像に対して，折 り返し成分を打ち消し, かつ雑音を低減するために複数枚 のフレーム画像の輝度平均をとる。

入力される $N$ 枚のフレーム画像を $L_{i}(x, y),(i=1$, $\cdots, N)$, 各フレーム画像における $x$ 方向, $y$ 方向の標本位 置のずれを $u_{i}, v_{i}$, 獲得できる高解像度画像を $S(x, y)$ と する。このとき, 平均によるフレーム画像の重ね合わせは (3) 式のように表される。

$$
S(x, y)=\sum_{i=0}^{N}\left\{L_{i}\left(x-u_{i}, y-v_{i}\right)\right\} / N \cdots \cdots \cdots
$$

この重ね合わせ処理においては, 他にも漸化式の解など として高解像度画像を導出する手法も提案されている (3)。 しかし, 目的である先行車両認識において, 高解像度化の 精度は必要であるが, 将来的にはハードウェアへの組み込 みシステムとして実現する必要があるため, 状況に対する ロバスト性と計算処理時間が精度以上に重要である。その ため, その両者に対して優れた利点を持つという点から, 本 研究では平均によるフレーム画像の重ね合わせ処理を採用 する。

〈2·3 重ね合わせ画像の画像復元 フレーム画像の 重ね合わせによって獲得された重ね合わせ画像は，この時 点で高解像度化が行われているが, 輝度平均による重ね合 わせ処理のために，重ね合わせ画像には同時に平滑化が行 われている。そのような重ね合わせ画像に対して, 画像復 元処理を施すことで, より鮮明な画像を獲得することを試 みる。

平滑化によるぼけを補正するため, 先鋭化手法の 1 つで あるアンシャープマスクを用いる。アンシャープマスクと は, 原画像からそのラプラシアン画像を減算する手法であ る。すなわち, 原画像を $f(x, y)$, 復元画像を $g(x, y)$ とす ると (4) 式で計算することができる。

$$
g(x, y)=f(x, y)-\nabla^{2} f(x, y)
$$

$\langle 2 \cdot 4\rangle$ 重ね合わせ画像に対する車両輪郭抽出上述 の手法で作成された高解像度画像に対して, 車両輪郭抽出 手法を適用することにより, 先行車両の認識精度の確認を 行う。

初めに紹介したように, 従来の先行車両認識手法では, 車両輪郭や車両のテールランプなど車両に付随する, さま ざまな車両特徵の情報を用いて先行車両を認識しているが, 


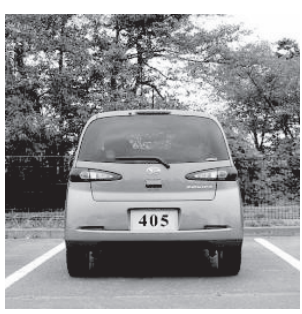

Fig. 1. Input Image

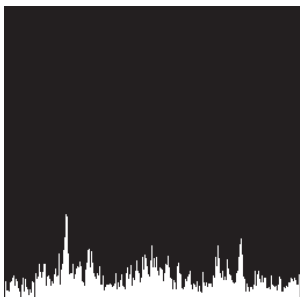

Fig. 3. Edge Histogram (horizontal axis)

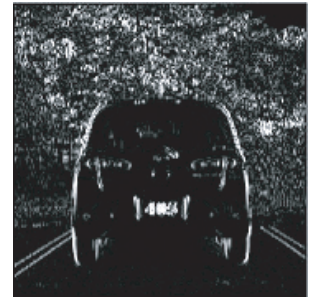

Fig. 2. Detected Edge

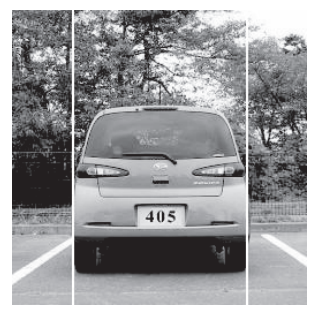

Fig. 4. Detected Vehicle
本研究では，その中でも特に重要な車両特徵として位置付 けられている車両輪郭に対象を絞ることとする。また，車 両輪郭には大きく分けて, 車両左右の輪郭, 車両の屋根と 底部の輪郭があるが，その内，車両屋根部分の輪郭におい ては，輪郭情報の抽出が困難であり，屋根部だけを抽出す ることに特化したアルゴリズムを必要とする。そのような アルゴリズムを用いると，一般性を失う可能性があるため， 本研究では車両左右の輪郭に対象を絞って認識処理を適用 する。

車両輪郭を抽出するために，まず Fig.1のような撮影画 像に対して，輪郭 (以下，エッジと呼ぶ) 要素を抜き出すた め，画像の濃淡変化に対し空間微分を行う。撮影画像に対 して空間微分を行った結果を Fig2 に示す。水平方向にのみ 空間微分を行うことで，Fig.2のように画像中の垂直エッジ 要素のみを抜き出すことができる。

次に, 微分画像に関するエッジヒストグラム情報の解析 を行う。エッジヒストグラムとは，対象となる軸（ここで は $x$ 軸）に沿ってどれだけのエッジ要素が検出されている かの分布を示すグラフのことを指す。Fig.2 に対してエッジ ヒストグラム情報を表示した画像を Fig.3に示す。

エッジヒストグラムの情報を解析することにより，画像 中の水平成分・垂直成分に特徴を持つような物体を抽出す ることが可能となり，特に，道路情景画像においては，道 路情景画像におけるエッジヒストグラム中のエッジの分布 が大きい点，つまりエッジ強度の強い点を車両輪郭として 抽出できることが知られている(1)。Fig.3におけるエッジ ヒストグラム情報を用いて，Fig.1にある対象車両の輪郭 抽出を行った結果を Fig.4に示す。

$\langle 2 \cdot 5\rangle$ 道路構造物の認識道路構造物は, 車両と比 較してエッジヒストグラム上で扇状にヒストグラム外側へ 広がる特徴を持っており，時系列でのエッジヒストグラム 情報の推移を観測することから，道路構造物として認識す

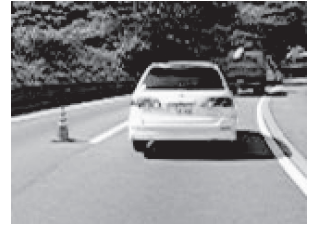

Fig. 5. Input Image

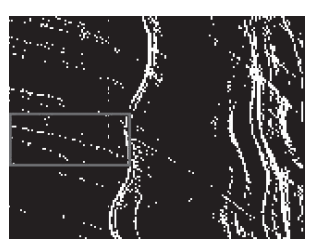

Fig. 6. Edge Transition

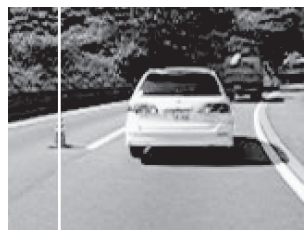

Fig. 7. Detect Object

\section{ることが可能となっている。}

ここで，エッジ情報の推移グラフとは，Fig.2で表示した ようなエッジヒストグラム情報を用いて, 動画中のフレー ム画像におけるエッジ強度の高い位置を時系列に記述した グラフである。グラフは，水平方向がある時刻におけるフ レーム画像の水平位置, 垂直方向が動画像における時間の 推移を示しており，ある時刻におけるフレーム画像中のエッ ジ強度が高い水平位置を白点として記述する。このグラフ において, 先行車両輪郭の情報が捕捉できていれば，先行 車両認識技術の適用が可能であると判断できる。

Fig.5 におけるエッジ情報の推移グラフを Fig.6 に示す。 また, Fig.6 のグラフ情報を基にして, 道路構造物認識を 行った結果を Fig.7 に示す。

\section{3. 検証実験}

実際の道路走行時において, 車載カメラから獲得された 動画像に対して提案手法を適用し, 車両輪郭の検出精度を 確認する。

入力動画像は, 乗用車両助手席前のダッシュボードに設置 したSONY DCR-TRV900 によって晴天昼間に30fps で撮 影したものである。カメラの解像度は QVGA $(320 \times 240)$ サイズを使用している。また，遠方であると白線に近接す るため, 白線に一番近い白色の車体の検出精度が悪くなる ことが経験的に知られている。そのため, 本実験では先行 車両の実験サンプルとして, 白色の車体を持つ車両にて実 験を行った。

〈3・1〉 エッジヒストグラム情報による評価はじめ に，提案手法適用前の車載カメラから獲得されたフレーム 画像に対してエッジヒストグラム情報を表示する。その後, 車載カメラから獲得されたフレーム画像のうち，8フレー 厶毎に提案手法を用いて 1 枚の高解像度画像を獲得する。 それによって作成された高解像度画像に対してもエッジヒ ストグラム情報を表示させることで, 提案手法適用前後で の精度の変化を確認する。

提案手法適用前の車載カメラから獲得されたフレーム画 


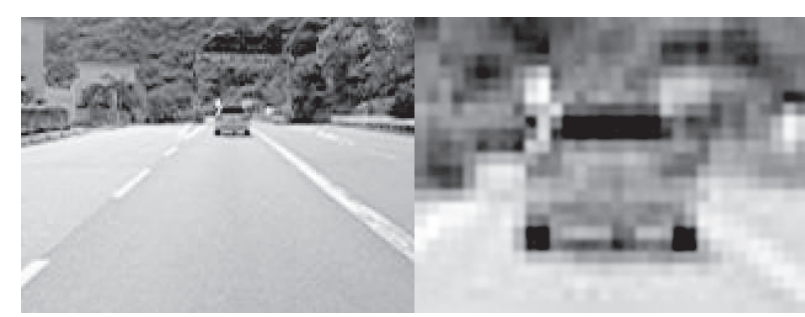

Fig. 8. Input Image on Real Road

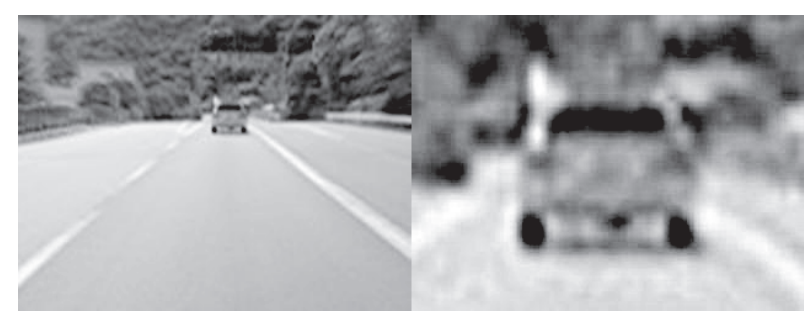

Fig. 9. SR Image on Real Road

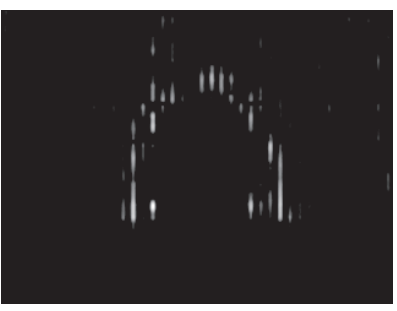

Fig. 10. Detected Edge (Input Image)

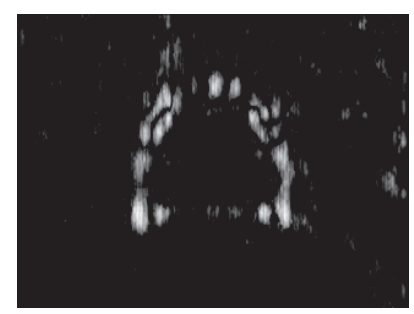

Fig. 11. Detected Edge (SR Image)
像を Fig.8 に, Fig.8 のフレーム画像を含み過去 8 フレー ムを用いて提案手法を適用したものを Fig.9に示す。

Fig.8 およびFig.9 では，視覚的な解像度向上の確認を容 易にするため, 眓中右部に先行車両領域の拡大困を示して いる。実験に用いた環境は, CPU:Core 2 Duo 2.13GHz, 主記憶:1024MB, OS:Windows XP で実行し, 高解像度画 像 1 フレームを作成するに要した計算時間は $26 \mathrm{~ms}$ であっ た。この結果は, 現在車両に積載されているハードウェア において十分実現可能な計算時間となっており, リアル夕 イムなシステムへの応用が期待できる。

Fig.8 と同様の走行動画像において，水平方向への空間 微分を行った結果を Fig.10 および Fig.11に，エッジヒス トグラム情報を表示させたものを Fig.12 および Fig.13に 示す。ここでは，提案手法の効果を明示するために，対向 車両とすれ違う走行画像を使用している。

Fig.12 およびFig.13にある提案手法適用前後のエッジ ヒストグラム情報において，2つの特徴が確認できる。1つ は, 提案手法適用前後で解像度が向上しているため, 車両 位置における輪郭特徴のエッジ幅が細かくなっている点で ある。そしてもう 1 つは, 動画像のフレーム画像を複数枚 合成するため，画像中の移動量の大きい物体には重ね合わ せによるぶれが発生する。これは，Fig.12 およびFig.13の 画像中に存在する対向車両にて確認できる。そのような画

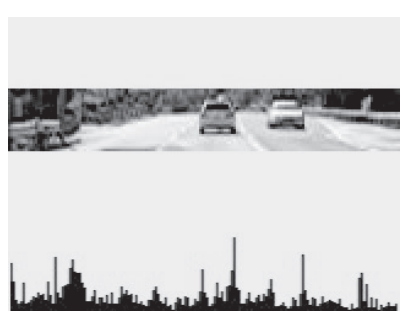

Fig. 12. Edge Histogram (Input Image)

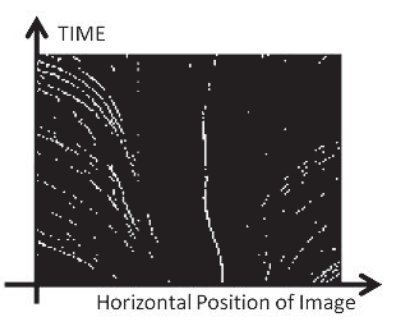

Fig. 14. Edge Transition (Input Image)

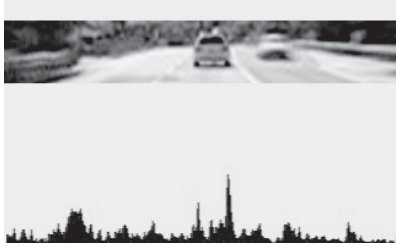

Fig. 13. Edge Histogram (SR Image)

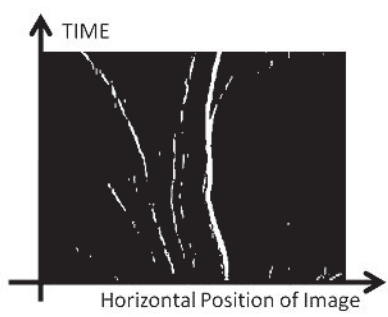

Fig. 15. Edge Transition (SR Image)
像中の移動量の大きい物体は, ぶれによって提案手法適用 前後でエッジヒストグラム情報に変化が現れる。これらの ことから, 提案手法を適用すると, 先行車両部分のような 遠方にある移動量の少ない物体においては, 輪郭特徵であ るエッジ情報が精細になり，近距離にある障害物のような 移動量の多い物体においては, エッジ情報が低減し, 誤検 出の防止が可能であることが確認できた。

〈3・2〉 エッジ情報の推移グラフによる評価＼cjkstart前述の 実験結果から提案手法により輪郭特徴であるエッジ情報の 改善の効果は確認できた。しかし， < $3 \cdot 4>$ 節の車両輪郭 抽出手法で用いたような理想的な標本画像とは異なり, 実 際の道路走行における車載カメラの動画像ではさまざまな 外乱が予想され, 単純にエッジ強度が一番強い位置を車両 輪郭として特定付けることができない。そこで，〈3・5> 節で説明を行ったエッジ情報の推移グラフによって, 輪郭 抽出精度の向上を確認する。

Fig.8で用いた道路走行動画像おいてエッジ情報の推移 グラフを確認する。本論文では, エッジ強度の強い上位 10 点を抽出している。提案手法適用前の推移グラフを出力し た結果を Fig.14に, 提案手法適用後の推移グラフを出力し た結果を Fig.15に示す。また, 手作業により正確に先行車 両輪郭のエッジ情報の推移グラフを作成した結果を Fig.16 に示す。

Fig.14 およびFig.16 を比較すると, 提案手法適用前で は先行車両左側の車両輪郭情報が弱いため車両左部の輪郭 を抽出することができていないことが確認できる。本研究 で用いた動画像は, 進行方向に対して左側から日光が差し ており，そのような状況下では Fig.14のように車両左側の 車両輪郭情報が弱くなる傾向にある。特に先行車両が遠方 にある場合，その影響が著しく表れ，その結果，Fig.14の 


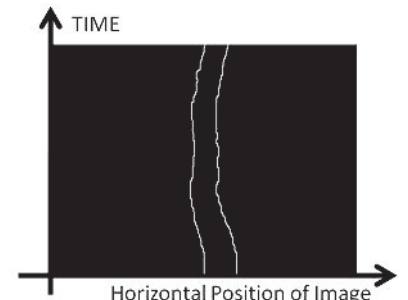

Fig. 16. Edge Transition (True Image)

Table 1. Evaluation of Edge Transition

\begin{tabular}{|c||c|c|}
\hline & Original & Proposed Method \\
\hline Evaluation Value & 0.0083 & 0.5041 \\
\hline
\end{tabular}

Table 2. Evaluation of Edge Transition (Another Scene)

\begin{tabular}{|c||c|c|}
\hline & Original & Proposed Method \\
\hline Left curve & 0.4958 & 0.8750 \\
\hline Right curve & 0.2458 & 0.8041 \\
\hline
\end{tabular}

ように周囲の道路構造物の輪郭情報を抽出することとなる。 そのような状況下において提案手法を適用することで，先 行車両右側の車両輪郭情報を強く獲得できると共に，提案 手法適用前では抽出することができなかった先行車両左側 の車両輪郭情報を獲得できていることが確認できる。

ここで，提案手法による車両輪郭抽出精度の向上を定量 的に評価するため，以下の (5) 式に示す評価值を算出する。

$$
\text { 評価值 }=\frac{\text { 正確に輪郭抽出できたフレーム数 }}{\text { 全フレーム数 }} \cdots
$$

これは，事前に作成したおいた Fig.16における正しい 先行車両輪郭情報を基に，提案手法適用前または後の推移 グラフと比較して, 正確に先行車両輪郭が抽出できている フレームの割合を示す評価值である。評価值はすべてのフ レームにおいて先行車両輪郭が正しく抽出できていれば， 1 を示す。また，対象となる輪郭情報が正しい先行車両輪郭 から 2 画素以内であり，かつ車両の左右両方の輪郭を検出 できている場合に正確に車両輪郭が抽出できていると判断 する。

Fig.14 およびFig.15における推移グラフに対して，評 価值を求めた結果を Table1 に示す。

また，Fig.17 および Fig.18のような異なる走行状況にお いて，前述と同様の処理を行った。提案手法適用前後のエッ ジヒストグラム情報変化の確認として, Fig.18 を拡大した 画像のエッジヒストグラム情報を表示したものを，Fig.19 および Fig20に示す。また，Fig.17 および Fig.18の走行 状況において，評価值 $((5)$ 式) を算出した結果を Table2 に 示す。

Table1 および Table2 から，提案手法を用いることで， 動画中の先行車両の輪郭抽出精度を改善できることが確認 できる。

$\langle 3 \cdot 3\rangle$ 合成位置特定のずれによる精度の評価

本研

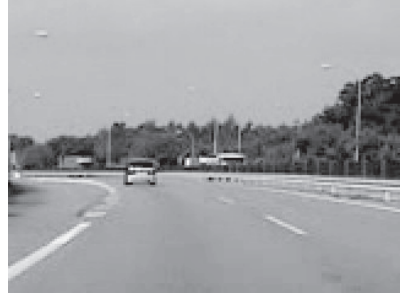

Fig. 17. Another Image (Left curve)

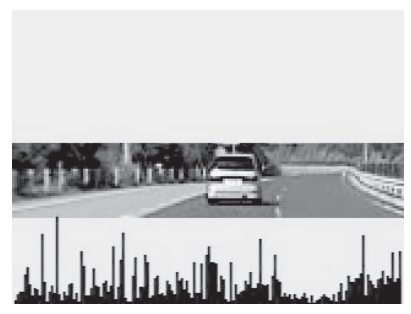

Fig. 19. Edge Histogram (Normal Fig.18)

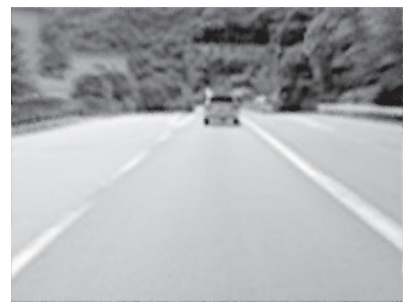

Fig. 21. Input Image $($ Error \pm 1$)$

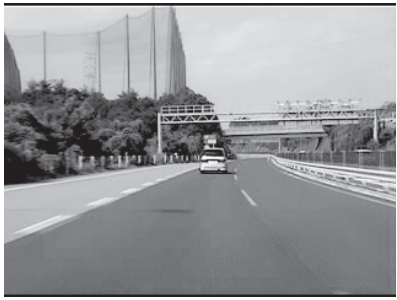

Fig. 18. Another Image (Right curve)

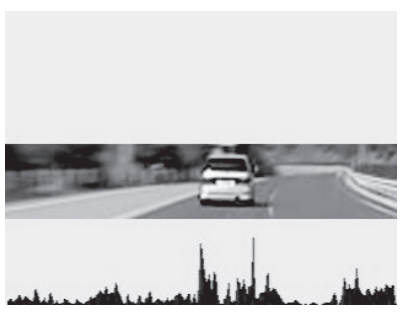

Fig. 20. Edge Histogram (SR Fig.18)

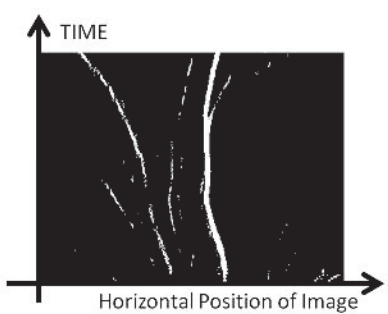

Fig. 22. Edge Transition $($ Error \pm 1$)$
究では，今後の展望として，自車のヨーレートなど，車両 のハードウェアセンサーの情報から合成位置を特定するよ うな手法について検討を行っている。しかし，テンプレー トマッチング処理と異なり, サブピクセル単位での位置特 定が困難となり，フレーム画像間の重ね合わせ位置にずれ が発生する可能性がある。ここで，重ね合わせ位置特定を する際に任意に誤差を与えることで，フレーム画像間の重 ね合わせ位置のずれがもたらす車両輪郭抽出精度への影響 について確認を行う。

提案手法適用の際，重ね合わせ位置特定処理時に誤差 \pm 1 を与えた重ね合わせ画像を Fig. 21 に，その際のエッジ情報 の推移グラフを Fig. 22 に示す。また, 䛊差 \pm 2 を与えた重 ね合わせ画像を Fig. 23 に，その際のエッジ情報の推移グラ フを Fig. 24 に示す。さらに, Fig.22 および Fig.24に対す る評価值 $((5)$ 式) を Table3 に示す。

Table3 から，合成位置特定において，位置特定誤差が発 生すると, 車両輪郭抽出精度に非常に影響をもたらすこと が確認できる。この結果から, 最低でも重ね合わせ位置特定 の誤差は 1 画素以内に収めなければならないことがわかる。 
Fig. 23. Input Image (Error \pm 2 )

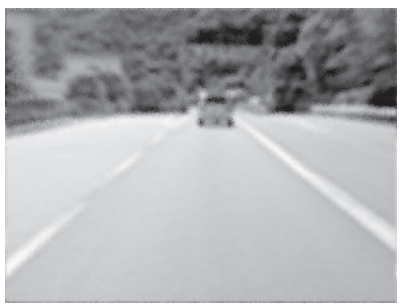

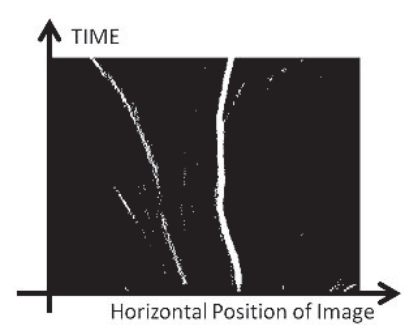

Fig. 24. Edge Transition (Error \pm 2$)$
Table 3. Evaluation of Error Image

\begin{tabular}{|l||c|c|c|}
\hline & Error \pm 0 & Error \pm 1 & Error \pm 2 \\
\hline Evaluation Value & 0.5041 & 0.2458 & 0.0208 \\
\hline
\end{tabular}

\section{4. まとめ}

本論文では，遠方にある先行車両の認識の信頼性向上を 目的に，入力となる動画像のフレーム画像を重ね合わせる ことによる遠方車両の解像度向上手法を提案した。この手 法では，テンプレートマッチングによって合成位置を決定 された複数枚のフレーム画像に対して，平均による重ね合 わせ処理を行い，さらに作成された重ね合わせ画像に対し てアンシャープマスクによるぶれ補正処理を施すことで高 解像度画像を獲得する。実際の道路走行動画像に対して提 案手法を適用し, 提案手法適用前後での車両輪郭抽出精度 を比較することにより本手法の有効性を示した。

また，本論文では，合成位置特定処理において，テンプ レートマッチングによる位置特定手法を用いた。しかし，今 後はより高速に計算できるように，自車のヨーレートなど， 車両のハードウェアセンサーの情報から合成位置を特定す るような手法について検討したい。また，現在はパーソナ ルコンピュータ上にてすでに撮影された動画像を用いてシ ミュレーションを行っているが, 本手法をリアルタイムに 動作可能なシステムを構築し, 実際に車両に搭載すること で,ささざまな道路情景に対して実験を行い, 手法のロバ スト性を確認したい。

(平成 19 年 10 月 25 日受付, 平成 20 年 3 月 31 日再受付)

\section{文献}

（1）山代華子 ·伊東敏夫 ·森 亮憲：「単眼カメラを用いた先行車両初 期捕捉手法」, 自動車技術会出版, 2007 年春季学術講演会前刷集, No.56-07 画像処理, 20075019 (2007)

(2) 下村倫子·中村 聡·後藤敏行・藤本和已·室 英夫:「車載カメラと
レーザレーダフュージョンによる前方車両追跡」，電学論 C， 123, 8, pp.1427-1438 (2003)

(3) S. C. Park, M. K. Park, and M. G. Kang: "Super-Resolution Image Reconstruction -A Technical Overview-", Signal Processing Magazine, Vol.20, No.3, pp.21-36 (2003)

（4）美齊津宏幸・稲村 實:「ランダムにサブピクセルシフトした低解像 度画像を用いた反復逆投影法による超解像再構成」, 信学技報。CS, 通信方式，Vol.106，No.421，pp.25-30 (2006)

（5）青木 伸：「複数のデジタル画像データによる超解像処理」, Ricoh Technical Report, No.24, pp.19-25 (1998)

寒 澤 佑 介（非会員） 1984 年生。 2007 年 3 月 神戸大学工

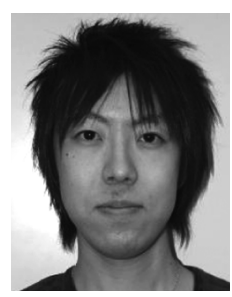
学部情報知能工学科卒業。同 4 月 神戸大学工学 研究科情報知能学専攻修士博士前期課程入学。現 在, 車載カメラの応用システムに関する研究に従 事。自動車技術会会員。

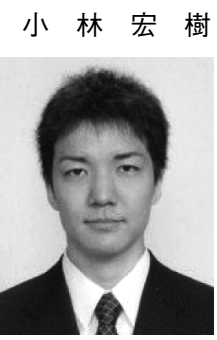

(非会員) 1983 年生。 2006 年 3 月 神戸大学工 学部情報知能工学科卒業。2008 年 3 月 神戸大 学工学研究科情報知能学専攻修士博士前期課程修 了。在学時, 車載カメラの応用システムに関する 研究に従事。

大 川 剛 直 (正員) 1963 年生。1986 年 大阪大学工学部通信

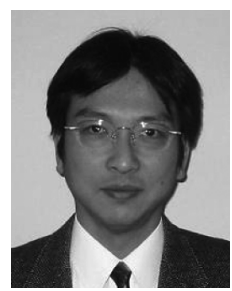
工学科卒業。1988 年 同大学大学院工学研究科通 信工学専攻博士前期課程修了。大阪大学助手, 講 師, 助教授を経て, 2005 年 神戸大学大学院自然 科学研究科教授。現在, 同大学大学院工学研究科 教授。博士 (工学)。知的ソフトウェア, バイオイ ンフォマティクスなどの研究に従事。IEEE，情 報処理学会, 電子情報通信学会などの会員。

伊 東 敏 夫（非会員） 1957 年生。1982 年神戸大学工学部

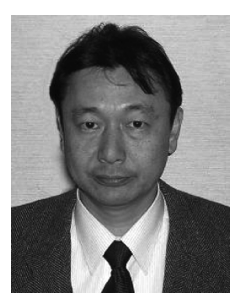
システム工学科卒業。同年, ダイハツ工業（株） 入社。1988 年より画像処理に興味を覚え, 衝突 防止装置等の車載カメラ応用システムの研究を開 始し現在に至る。博士 (工学)。1993 年 システ 厶制御情報学会椹木記念賞論文賞受賞。自動車技 術会, 電子情報通信学会, システム制御情報学会, IEEE 等各会員。 